\title{
Training and Employee Performance in Microfinance Institutions of North-Kivu in the Democratic Republic of Congo
}

\author{
Kavugho Ngamuvyaki Neema \\ Catholic University of Graben, Butembo, North-Kivu, Democratic Republic of the Congo \\ Email: neemangamuvyaki@gmail.com
}

How to cite this paper: Neema, K. N. (2022). Training and Employee Performance in Microfinance Institutions of North-Kivu in the Democratic Republic of Congo. Open Journal of Business and Management, 10, 101-117.

https://doi.org/10.4236/ojbm.2022.101006

Received: November 20, 2021

Accepted: December 27, 2021

Published: December 30, 2021

Copyright $\odot 2022$ by author(s) and Scientific Research Publishing Inc. This work is licensed under the Creative Commons Attribution International License (CC BY 4.0).

http://creativecommons.org/licenses/by/4.0/

\begin{abstract}
The paper established the relationship between training (training needs, training contents, training methods, training evaluation) and performance of employees in Microfinance Institutions located in North-Kivu. Using Slovin's formula, a sample size of 110 was derived from the total research population of 152 employees in microfinance institutions. The purposive sampling technique was used for this study. The tool used to collect data in this study was questionnaire and reliability of the research instruments was ensured through test and expert judgment respectively. The statistical tools used to analyze data in this study were correlation analysis and multiple regression analysis and these were done using SPSS (v.20). The results indicate that there is a positive relationship between training needs assessment and employee performance in Microfinance Institutions located in North-Kivu ( $r=0.612$; sig. $=0.000$ ), that any variation in training contents will lead to significant and positive variation in employee performance in Microfinance Institutions situated in North-Kivu $(r=0.0544$; sig. $=0.000)$; that there is a positive relationship between training methods and employee performance in Microfinance Institutions located in North-Kivu $(r=0.496$; sig. $=0.000)$ and that effectiveness in training evaluation positively and significantly influences employee performance in Microfinance Institutions situated in North-Kivu $(r=$ 0.62 ; sig. $=0.000)$.
\end{abstract}

\section{Keywords}

Training, Employee Performance, Microfinance Institutions, North-Kivu

\section{Introduction}

As one of major activities of human resource management, training has for long 
been recognized to improve and develop employee performance (Sultana et al., 2012; Pfeffer, 1994). In order to prepare their workers to do their jobs as desired, organizations provide training to optimize employee's potential (Tahir, 2014; Nassazi, 2013). According to Swart et al. (2005), training increases workers' productivity also improves the services of the workers and brings optimistic change in the organization. According to Buckey \& Caple (2000) and Belcourt \& Saks (2000), training is a systematic process, which helps people to learn how to be more effective at work by modifying knowledge, skills or attitudes through learning experience to achieve effective performance.

In microfinance, employees are the valuable asset as they can make or break microfinance's reputation and can adversely affect profitability (Adeleye et al., 2014). Training enables employees to deal with the customer in an effective manner and respond to their complaints in a timely manner (Elnanga \& Imran, 2013). Most of the firms invest in the building of new skills by their workforce, enabling them to cope with the uncertain conditions that they may face in future; thus, improving the employee performance (Ameeq \& Hanif, 2013).

Microfinance Institutions in North-Kivu have invested in training in order to achieve performance. With training programs in place, one would expect improvement of employee performance since effective training programs help employees to get acquaintance with the desired new changes, also gainful command on the competencies and skills required to perform a particular job and to avoid on the job errors and mistakes (Roberts, 2006). However, there is evidence of poor performance. This study therefore, goes on to discuss training, employee performance, and how training affects employee performance.

In the effort of finding the solution for this study, the research tried to find out the following objectives: To assess the relationship between training needs assessment and employee performance in Microfinance Institutions; To examine the relationship between training contents and employee performance in Microfinance Institutions; To establish the relationship between training methods and employee performance in Microfinance Institutions; To determine the relationship between training evaluation and employee performance in Microfinance Institutions.

This study helped microfinance institutions understand the importance of training to overcome challenges faced. It also enabled them structure their training and make them more effective in terms of helping to improve the efficiency of the workforce and to lead to better performance. This also ensured the existence of a pool of skilled workforce who could be utilized for national development.

Several studies have been carried out on the effects training including Githinji (2014) who did the study on the effects of training on employee performance: A case study of United Nations support office for African union mission in Somalia. The study showed that training influences employee performance by positively influencing employee engagement to change process; innovation; better 
performance and enhance enthusiasm to work. Benedicta (2010) carried out the study on the impact of training on employee performance: A case study of HFC bank (Ghana). His study revealed that training has impact on the performance of employees who work in HFC bank. Nassazi (2013) did a study on effects of training on employee performance; Evidence from Uganda. He found that training and development have an impact on the performance of employees with regards to their jobs.

To the best of our knowledge, no study has been published on training and employee performance in Microfinance Institutions of North-Kivu (DRC). Therefore, this study is carried out to fill this knowledge gap.

\section{Literature Review}

The literature relates the components of training and the employee performance that has been documented by various scholars and authors in the area of study.

\subsection{Training Needs}

"Training Needs Assessment" (TNA) is a process of collecting information about an expressed or an implied organizational need that could be met by conducting training (Barbazette, 2006). According to Goldstein \& Ford (2002) needs assessment or needs analysis seeks to answer the question of whether the organization's needs, objectives and problems can be met or addressed by training. The purpose of a TNA is to identify performance requirements and knowledge, skills, and abilities needed by an agency's workforce to achieve the requirements (Wagonhurst, 2002). TNA is a crucial initial step to design a training program and can substantially influence the overall effectiveness of training programs (Goldstein \& Ford, 2002).

\subsection{Training Contents}

Training contents include any and all information presented to learners with the aim of teaching knowledge or skills (Megan, 2017). According to Wexley \& Latham (2002), the need to consider skill and tasks characteristics in determining the most effective training delivery approaches should be highlighted. A number of typologies have been offered for categorizing skills and tasks (Gagne, Briggs, \& Wagner, 1997), which can be categorized into two broad categories: people or technical skills. People skills are typically hard to observe; quantify and measure as much as it needed for everyday life and in work because it has to do with how people relate to each other: communicating, listening, engaging in dialogue, giving feedback, cooperating as team member, solving problems and resolving conflicts (Coates, 2004). Organizations should also acknowledge that their employees have the latest technical skills training, which are designed and offered by organizations in updating their existing skills and acquiring new technologies that will best suit with organization's technical training needs, goals and budgets (Hamid et al., 1987). 


\subsection{Training Methods}

Training methods include but are not limited to:

\section{Job rotation and transfers}

Job rotation is the method which refers to the process whereby by the trainee moves from one function to another as the planned timetable or schedule will dictate (Adeleye et al., 2014). Transfers involve movement of employees from one country to another (McCourt \& Eldridge, 2003).

\section{Coaching andl or mentoring}

This involves having the more experienced employees with more specific of knowledge, skills and abilities in problem solving, conflict resolution, communication, goal setting and planning coach the less experienced employees (Torrinton et al., 2005). So the goal of mentoring is the exchange of knowledge so that the mentee is better socialize and becomes better prepared to take on important duties in the organization (Burges, 2007).

\section{Orientation}

This method deals with a situation whereby new employees are given training to enable them to get acquainted with the work and the organization as a whole in respect of values, rules and regulation (Olaniyan \& Ojo, 2008).

\section{Conferences}

This method involves presentations by more than one person to a wide audience. It is more cost effective as a group of employees are trained on a particular topic all at the same time in large audience (Cole, 2002).

\section{Role playing}

Trainees are provided with some information related to the description of the roles, concerns, objectives, responsibilities, emotions, and many more. Following is provision of a general description of the situation and the problem they face. The trainees are there after being required to act out their roles (Blatner, 1995).

\section{Formal training courses and development programs}

These courses and programs are usually a set of defined and known programs where the contents, durations and all the details about the training are clear to both the organization and the personnel to be trained (Ahammad, 2013).

Field trip or tour

Field trip or tour is usually observation for training and non-experimental research in order to provide employees with experiences outside of their everyday activities, which with the aim to observe its natural state and possibly collect sample in purpose of works tasks (Goldstein \& Ford, 2002).

\subsection{Training Evaluation}

The choice of evaluation criteria is a primary decision that must be made when evaluating the effectiveness of training. The main objective of training evaluation is to prove that the training has actually taught what was intended and to improve the course contents for future use (Goldstein \& Ford, 2002). 
However, training evaluation is a difficult and complex task (Arthur et al., 2003) but the most important activity in the training process because it is the final logical stage; and organizations should assess their training efforts systematically.

\subsection{Employee Performance}

According to Sultana et al. (2012), training is an effective tool to equip or push employees to improve upon their performance. Training is determined as the process of enabling employee to complete the task with greater efficiency, thus considered to be vital element of managing the human resource performance strategically (Huselid, 1995). Employee performance, achieved through training, refers to the enhancement of the knowledge, skills, and abilities acquired by employees so that they can perform their duties to achieve organizational goals (Huselid, 1995).

\subsection{Training and Employee Performance}

Learning through training influences the organization performance, and is said to be a key factor in achievement of corporate goals (Harrison, 2000). Implementing training programs as a solution to covering performance issues such as filling the gap between the standard and the actual performance is an effective way of improving employee performance (Swart et al., 2005). The employee superior performance occurs only because of a good quality training program that leads to employee motivation and their needs skills (Swart et al., 2005). According to Wright \& Geroy (2001), employee competencies change through effective training programs. It not only improves the overall performance of the employees to effectively perform the current job but also enhances the knowledge, skills and attitude of the workers necessary for the future job, thus contributing to superior organizational performance.

Many scholars or authors who dealt with training and performance, talked about training in a global way. In this paper, we try to deal in depth with the elements of training (training needs, training contents, training methods, training evaluation) and to highlight the influence of each component on employee performance in order to identify the overall relationship between training and employee performance.

\section{Methodology}

In this study, quantitative methods were used in order to determine the relationship between training (training needs, training contents, training methods, and training evaluation) and employee performance. Questionnaire was used to collect quantitative data. Through quantitative methods, data were analyzed and interpreted. The study was conducted in North-Kivu. The population was constituted of 152 employees, and the sample was constituted using Slovin's formula which is $n=N /\left(1+N e^{2}\right)$, where $N=152$ and $e=0.05$. From this formula, the 
sample $(n)$ of 110 employees was obtained. The sampling technique used in this study was purposive sampling. This technique was effective as it helped us to choose those employees who are able to give us detailed information on how the training received has influenced their performance. The study used both primary data and secondary data sources, where primary data were collected from employees of each organization using structured questionnaires and interviews and secondary data were collected from documentation, archival records, magazines, Internet and other documents which were relevant to the study.

\section{Results and Discussion}

Quantitative research was used for the purpose of this research because quantitative analyses results provide support for anticipated directions of the associations between independent and dependent variables. So by using SPSS version 20 for windows software, correlation between dependent and independent variables was examined. To analyze data we used techniques such as descriptive statistics, correlation analysis and multiple regression analysis.

\subsection{Descriptive Statistics}

Descriptive statistics is the way to summarize data which use tabular, graphical, or numerical. The descriptive statistics provides frequencies and measures of central tendency of this research analysis. So, frequencies of this analysis can be referred to histograms or bars charts of various subcategories, such as age, gender, marital status, education background, years of services. The main objective of conducting descriptive statistics is to make all data easier to read. There are 110 people participating in this survey. Hence, we use descriptive statistics to illustrate the socio-demographic profile of respondents.

1) Age analysis

Based on age the main respondent in this research is in the group 31-35 years old. This age largest group showed a percentage of $32 \%$. The second group was people that were 36 - 40 years old; this showed a percentage of $23 \%$. The third is the age between 26 - 30 years old that showed around of $17 \%$. The fourth was the group of people between 41 - 45 years old and showed a percentage of $11 \%$. The fifth is the age above 46 years and showed a percentage of $9 \%$. And the smallest group is the age bellow 25 years this is $8 \%$. This means that the force labor in Microfinance Institutions in North-Kivu has from 31 - 35 years old (Figure 1).

\section{2) Gender analysis}

This figure reflects the gender distribution of the participants in this research. The majority was male (females were $35 \%$ while males were $65 \%$ higher than females), which supports that the number of men who are working in Microfinance Institutions in North-Kivu is higher than the number of women (Figure 2).

\section{3) Marital status}

The result shows that status of distribution of the participants in this research. 


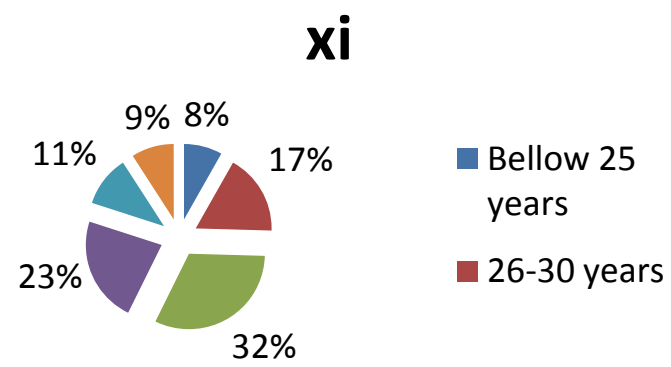

Figure 1. Age analysis. Source: Research data.

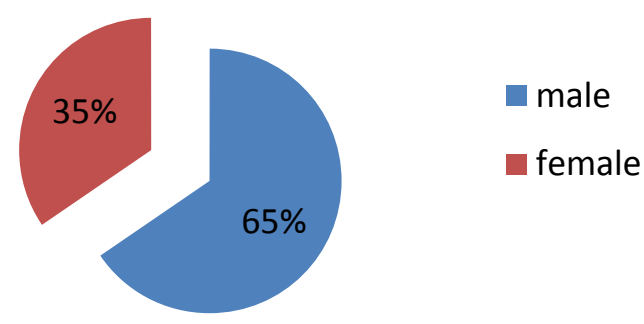

Figure 2. Gender analysis. Source: Research data.

The majority was $80 \%$ married while the single was $18 \%$, the separated $0 \%$ and the other case $2 \%$. This supports that the number of married persons who are working in Microfinance Institutions in North-Kivu is higher than the number of single and separated persons (Figure 3).

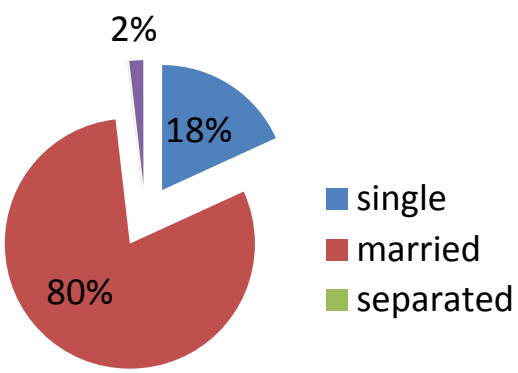

Figure 3. Marital status analysis. Source: Research data.

\section{4) Education background}

This chart presents that most of the respondents 54\% claimed that they have a post graduate level, followed by $34 \%$ who are graduates. Those with the state diploma had a percentage of $12 \%$. Master and PHD levels had $0 \%$. The majority was postgraduate level $54 \%$ is the force labor of these Microfinance Institutions (Figure 4).

\section{5) Years of service}

The chart presents that most of respondents "years of service above 5 years" is $50 \%$, followed by $23 \%$ who has year of service from 4 to 5 years, 1 - 3 years of service is a percentage of $19 \%$. And the percentage of $8 \%$ is years of service bellow 1 year (Figure 5). 


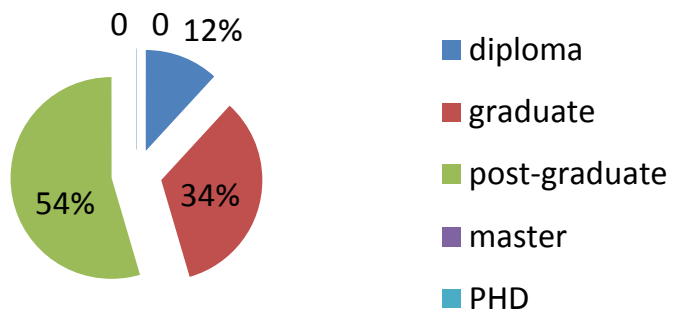

Figure 4. Education background analysis. Source: Research data.

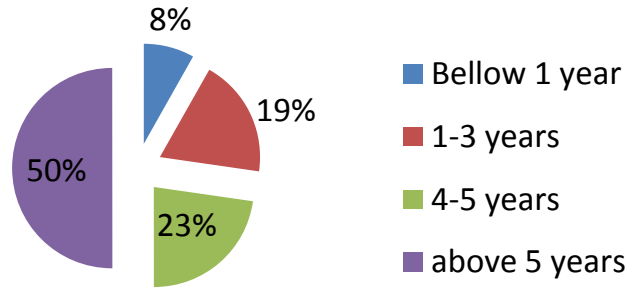

Figure 5. Years of service. Source: Research data.

\subsection{Correlation Analysis}

Before presenting the correlation analysis, we checked first the consistency of the variables using the reliability test.

Reliability Test

The reliability analysis is used to test consistency of respondents' answers to all the items of variables in the questionnaire, whether the items are hung together as a set which they are highly correlated with another (Cronbach, 1946). According to Cavana et al. (2001), Cronbach's alpha is a reliability coefficient that indicates how well the items in a set are positively correlated to one another.

A commonly accepted rule of Thumb for describing internal consistency using Cronbach's alpha is as in Table 1 (Cronbach, 1946).

Consistency of this research was examined through Cronbach's coefficient Alpha.

It can be seen for the independent variable that all the Cronbach's alphas are accepted and they are at a good level as they are all between 0.7 and 0.9 (Table 2 ). Hence the factors in training can be considered as well designed items and data are trustworthy.

It can be seen for the dependent variable that all the Cronbach's alphas are at the acceptable level since they are between 0.6 and 0.7 (Table 3). Therefore, performance can also be considered as well-designed items and data are trustworthy.

After the reliability test, we presented and discussed the results about the correlation analysis in the following sections:

The Pearson correlation coefficient, $r$, can take a range of values from +1 to -1 . If there is a strong positive linear relationship between the variables, the value of $\mathrm{r}$ will be close to +1 . If there is a strong negative linear relationship between the variables, the value of $r$ will be close to -1 . When there is no linear 
Table 1. Cronbach's alpha level.

\begin{tabular}{cc}
\hline Cronbach's alpha & Internal consistency \\
$\alpha \geq 0.9$ & Excellent (High-stakes testing) \\
$0.7 \leq a \leq 0.9$ & Good (Low-Stakes testing) \\
$0.6 \leq a \leq 0.7$ & Acceptable \\
$0.5 \leq a \leq 0.6$ & Poor \\
$\alpha<0.5$ & Unacceptable \\
\hline
\end{tabular}

Table 2. Reliability statistics for the independent variable.

\begin{tabular}{ccc}
\hline Variable & Cronbach's Alpha & N of Items \\
\hline Training needs & 0.861 & 8 \\
Training contents & 0.761 & 6 \\
Training methods & 0.714 & 8 \\
Training evaluation & 0.840 & 13 \\
\hline
\end{tabular}

Source: Author's calculation with SPSS software.

Table 3. Reliability statistics for the dependent variable.

\begin{tabular}{ccc}
\hline Variables & Cronbach's Alpha & N of Items \\
\hline Service quality & 0.747 & 7 \\
Dependability & 0.738 & 4 \\
Cooperativeness & 0.633 & 3 \\
Adaptability & 0.687 & 4 \\
Communication & 0.723 & 4 \\
\hline
\end{tabular}

Source: Author's calculation with SPSS software.

relationship between the variables or only a weak relationship, the value of $r$ will be close to 0 . The study variables were measured on a continuous scale, and thus Pearson correlation was found to the most appropriate to test the relationships between training and employee performance. The results are presented based on the objectives as follow:

Relationship between training needs and employee performance

The first objective of this study was to determine the relationship between training needs assessment and performance for the employees working in microfinance institutions sited in North-Kivu. To determine that relationship, a Pearson correlation was employed and findings are established in Table 4.

The findings presented in Table 4 indicate that there is a positive and significant relationship between training needs assessment and employee performance in microfinance institutions found in North-Kivu. Training needs assessment is correlated with employee performance with $r=0.612$. This means that any unit improvement in training needs assessment in Microfinance institutions leads to 
Table 4. Correlation between training needs assessment and employee performance.

\begin{tabular}{cccc}
\hline & & Training Needs & PERFORMANCE \\
\hline & Pearson Correlation & 1 & $0.612^{\star *}$ \\
Training Needs & Sig. (2-tailed) & & 0.000 \\
& $\mathrm{~N}$ & 110 & 110 \\
\hline & Pearson Correlation & $0.612^{\star *}$ & 1 \\
PERFORMANCE & Sig. (2-tailed) & 0.000 & 110 \\
\hline
\end{tabular}

Source: Author's calculation with SPSS software.

improvement of employee performance by 0.612 . Training needs assessment is a crucial initial step to design a training program and can substantially influence the overall effectiveness of training programs.

The above result confirms the study for Mutisya et al. (2017) in which they concluded that training needs assessment influence employee performance, therefore organization performance. The study specified that the most influential of the training needs assessment was individual needs assessment where individual training needs assessment involves taking into account both the needs of individuals, but also anything that can help the department/organization to work together as effectively as possible.

The results for this study regarding the relationship between training needs assessment and employee performance are in the same line with the work of Hartoyo \& Efendy (2017) where he found that the results of the analysis training needs are useful as a basis for making a decision in providing solutions to a performance problem. He concluded that training needs analysis developed and implemented can meet the needs and impact on improving performance.

The study findings by Anuar et al. (2015) are in line with the present findings of this study. It revealed that the right adoption of TNA process will increase effectiveness without wasting time, energy and money in order to achieve the desired performance.

The findings for this study regarding relationship between training needs assessment confirm the work for Humphrey et al. (2013) as his results indicated there was a positive and significant effect between training needs assessment and employee performance in Mumias Sugar Company Limited.

\subsubsection{Relationship between Training Contents and Employee Performance}

The second objective of this study was to determine the relationship between training contents and employee performance in microfinance institutions found in North-Kivu. To establish that link between training contents and employee performance, a Pearson correlation was also used and the findings regarding these are presented in Table 5. 
Table 5. Correlation between training contents and employee performance.

\begin{tabular}{lccc}
\hline & & Training Contents & PERFORMANCE \\
\hline & Pearson Correlation & 1 & $0.544^{\star \star}$ \\
Training Contents & Sig. (2-tailed) & & 0.000 \\
& $\mathrm{~N}$ & 110 & 110 \\
\hline & Pearson Correlation & $0.544^{\star *}$ & 1 \\
PERFORMANCE & Sig. (2-tailed) & 0.000 & 110 \\
\hline
\end{tabular}

Source: Author's calculation with SPSS software.

From these findings, it can be confirmed that there is the significant and positive linear relationship between training contents and employee performance. This result is confirmed by the Pearson correlation value $r=0.544$ and significant value 0.000 which is far less than the standardized significant value 0.05 . The result implies that any unit improvement in training contents in Microfinance institutions leads to improvement of employee performance by 0.544 .

Regarding the effect of training contents on employee performance, the above findings confirm the study for Huyen (2014) where he concluded that training contents significantly and positively influence employee performance.

Also findings for this study regarding relationship between training contents confirm the work for Humphrey et al. (2013) as his results indicated that there was a positive and significant effect between training contents and employee performance in Mumias Sugar Company Limited.

\subsubsection{Relationship between Training Methods and Employee Performance}

The third objective of this study sought to find out the relationship between training methods and performance of the employees in microfinance institutions situated in North-Kivu. As it was in the case of the first two research objectives, this research objective was established using correlation at the standardized significant value of 0.05 . The findings regarding this are presented in Table 6.

Taking into consideration the significant values presented in Table 6, it can be noted that training methods positively and significantly correlate to employee performance with $r=0.496$. This result means that the performance of the employees in microfinance institutions will be boosted by 0.496 in every unit improvement in the training methods.

The findings above are in agreement with the findings in the study of Nassazi (2013) which suggested that training methods have an impact on the performance of employees with regards to their jobs.

Regarding the effect of training contents on employee performance, the above findings confirm the study for Huyen (2014) where he concluded that training contents significantly and positively influence employee performance. 
Table 6. Correlation between training methods and employee performance.

\begin{tabular}{lccc}
\hline & & Training Methods & PERFORMANCE \\
\hline & Pearson Correlation & 1 & $0.496^{* *}$ \\
Training Methods & Sig. (2-tailed) & & 0.000 \\
& N & 110 & 110 \\
\hline & Pearson Correlation & $0.496^{* *}$ & 1 \\
PERFORMANCE & Sig. (2-tailed) & 0.000 & 110 \\
\hline
\end{tabular}

Source: Author's calculation with SPSS software.

\subsubsection{Relationship between Training Evaluation and Employee Performance}

The last specific objective of this study was to examine the relationship between training evaluation and the performance of employees in microfinance institutions located in North-Kivu. To determine the relationship between training evaluation and employee performance in microfinance institutions, a Pearson correlation was used and the findings are established in Table 7.

The findings presented in Table 7 indicate that there is a positive and significant relationship between training evaluation and performance with $r=0.62$ and significant value of 0.000 . This result implies that any unit improvement in training evaluation leads to improvement of performance by 0.62 . Training evaluation is the most important activity in the training process because it proves that the training has actually taught what it was supposed to teach and improves the training contents for future use.

The above findings on relationship between training evaluation and employee performance are in agreement with the one by Wanigasingha et al. (2018) in which they established that more than $60 \%$ nurses were satisfied with the training evaluation system. There was a positive a significant relationship between training evaluation and performance in $\mathrm{ABC}$ Hospital. Training is a very important part of training programs which provide a feedback about the training program.

The findings regarding effect of training evaluation on employee training are in agreement with the work of Emerso (2017) in which he was able to find that training evaluation is positive and significantly correlated to employee performance.

The findings for this study about the relationship between training evaluation and employee performance confirms the findings of Mohammed (2018) where the results indicated that trainer performance was positively and significantly related to training outcomes: reaction, learning; behavior and in addition, training environment had a strong and positive impact on learning.

\subsection{Multiple Regression Analysis}

This analysis was used to increase the accuracy of predictions for the dependent 
Table 7. Correlation between training evaluation and employee performance.

\begin{tabular}{lccc}
\hline & & Training evaluation & PERFORMANCE \\
\hline & Pearson Correlation & 1 & $.620^{* *}$ \\
Training evaluation & Sig. (2-tailed) & & 0.000 \\
& $\mathrm{~N}$ & 110 & 110 \\
\hline & Pearson Correlation & $0.620^{* *}$ & 1 \\
PERFORMANCE & Sig. (2-tailed) & 0.000 & 110 \\
\hline
\end{tabular}

Source: Author's calculation with SPSS software.

Table 8. Model summary.

\begin{tabular}{|c|c|c|c|c|c|c|c|c|c|c|}
\hline \multirow{2}{*}{ Model } & \multirow{2}{*}{$\mathrm{R}$} & \multirow{2}{*}{ R Square } & \multirow{2}{*}{$\begin{array}{l}\text { Adjusted R } \\
\text { Square }\end{array}$} & \multirow{2}{*}{$\begin{array}{l}\text { Std. Error of } \\
\text { the Estimate }\end{array}$} & \multicolumn{5}{|c|}{ Change Statistics } & \multirow{2}{*}{ - Durbin-Watson } \\
\hline & & & & & R Square Change & F Change & df1 & $\mathrm{df} 2$ & Sig. F Change & \\
\hline 1 & $0.656^{\mathrm{a}}$ & 0.431 & 0.425 & 0.393 & 0.431 & 81,693 & 1 & 108 & 0.000 & 1626 \\
\hline
\end{tabular}

Source: Author's calculation with SPSS software. a. Predictors: (Constant), TRAINING; b. Dependent Variable: PERFORMANCE.

variable over the independent variable. To verify the research findings obtained through correlation, multiple regression analysis was employed and the findings regarding these are presented in Table 8.

The results of primary interest are the $\mathrm{R}$ square and the Adjusted $\mathrm{R}$ Square values, which are 0.431 and 0.425 respectively. We learn from these that the overall variance (employee performance) explained by training is $42.5 \%$. In other words, $42.5 \%$ of the variance in employee performance is predictable from training. This is well understood as employee performance is not only influenced by only training in Microfinance Institutions but it might also be influenced by other factors such as credit risk management, financial resources. Training alone occupies $42.5 \%$ in the influence of employee performance.

\section{Conclusions and Recommendations}

Regarding the relationship between training needs assessment and employee performance in microfinance institutions located in North-Kivu, this study concludes that there is a positive and significant relationship between training needs assessment and employee performance thus any unit improvement in training needs assessment in microfinance institutions located in North-Kivu leads to improvement of employee performance by 0.612 .

Concerning the relationship between training contents and employee performance in microfinance institutions situated in North-Kivu, this research concludes that any improvement in training contents for employees working in microfinance institutions situated in North-Kivu will lead to positive and significant improvement of their performance by 0.544 .

On the association between training methods and performance for employees 
working in Microfinance institutions located in North-Kivu, this study concludes that there is a positive and significant correlation between training methods and employee performance thus, the improvement in one unit in training methods leads to employee performance improvement in 0.496 in microfinance institutions located in North-Kivu.

Finally, on the relationship between training evaluation and performance for employees in microfinance institutions situated in North-Kivu, this study concludes that effectiveness in training evaluation significantly and positively influences the performance of the employees in microfinance institutions in North-Kivu, thus any unit improvement in training evaluation leads to improvement of employee performance by 0.62 .

The results of this research can easily be generalized to a wider population as the sample was representative.

From the foregoing, the study proposed the following recommendations to improve the efficiency and effectiveness of training:

1) Training needs should start with explanation about the essence of training so that employees identify the real and strong needs for training, otherwise they may present needs which are fictive and which will not have great influences on work performance.

2) Managers should well plan about the content of training based on training needs established by the employees as the relationship between training contents and employee performance is not strong. This will help training to cover the gap it is intended to cover.

3) Managers should also choose the training methods which fit with the organization mission, vision, values, and culture to make sure trainees acquire desired skills, knowledge and attitudes during training. This is will help to get a strong relationship between training methods and employee performance.

4) Training evaluation should be a current activity in MFIs as it influences performance. Future training depends on training evaluation because it is the only step which shows whether training taught what is it is intended to teach. Therefore it should be done carefully to rise up gaps which training did not cover.

Usually, it is almost impossible for a piece of work of this nature to be realized without limitations. Firstly, the study focused only on fewer employees or subordinates. It did not include managers or the hierarchy level. Secondly, the study of insecurity in other territories of North Kivu limited the research to only three cities which are Beni, Butembo and Goma. It was impossible to reach the areas where there is massacre and war.

A number of topics for future research can be identified. Future research can look at the hierarchy level and see if training managers can also influence their performance as well as the performance of the whole organization, because it is not enough to train employees if their managers are not too. In addition, future studies may compare the training of employees to that of managers and see 
which affects mostly the performance of the organization so that it is followed with much attention. Moreover, future research should consider all Microfinance institutions from all the corners of the province as soon as there is pacification of territories under war.

\section{Conflicts of Interest}

The author declares no conflicts of interest regarding the publication of this paper.

\section{References}

Adeleye, A., Stephen, A., \& Helen, O. (2014). Training and Manpower Development in Public Research and Development Organizations. International Journal of Academic Research in Management, 3, 215-232. http://elvedit.com

Ahammad, S. (2013). Importance of Training in the Hotel Industry: A Case Study of Hilton Hotel. Master Thesis, Sodertons University, School of Business Studies. https://www.semanticscholar.org

Ameeq, U., \& Hanif, F. (2013). Impact of Training and Development Programs on Employee Performance. International Journal of Scientific and Research Publications, 5, 42-48. http://www.ijsrp.org

Anuar, M., Nassir, A., Manhood, A., \& Ahmed, A. (2015). A Study on Training Needs Analysis (TNA) Process among Manufacturing Companies. Mediterranean Journal of Social Sciences, 6, 670-679. https://www.researchgate.net

Arthur, W., Bennett, W., Edens, P., \& Bell, S. (2003). Effectiveness of Training in Organization: A Meta-Analysis of Design and Evaluation Features. Journal of Applied Psychology, 88, 234-245. https://psycnet.apa.org https://doi.org/10.1037/0021-9010.88.2.234

Barbazette, J. (2006). Training Needs Assessment: Methods, Tools, and Techniques. Pfeiffer.

Belcourt, M., \& Saks, A. (2000). Managing Performance through Training and Development (2nd ed.). Nelson Series. https://books.google.com

Benedicta, A. (2010). The Impact of Training on Employee Performance: A Case Study of HFC Bank (Ghana) Limited. Ashesi University College, Business Administration, https://www.researchgate.net

Blatner, A. (1995). Role Playing in Education. Youth Theater Journal, 9, 92-96. https://www.blatner.com https://doi.org/10.1080/08929092.1995.10012469

Buckey, J., \& Caple, A. (2000). Practising Education, Training and Development (4th ed.). Korgan.

Burges, R. (2007). Mentoring as Holistic Online Instruction. New Directions for Adult and Continuing Education, 49-56. https://onlinelibrary.willey.com

Cavana, R. L., Delahaye, B., \& Sekaran, U. (2001). Applied Business Research: Qualitative and Quantitative Methods. John Wiley\& Sons Inc. https://www.scrip.org

Coates, E. (2004). People Skills Training: Are You Getting a Return on Investment? Performance Support System. https://www.2020insight.net

Cole, G. A. (2002). Personnel and Human Resource Management. Work Publishers. https://www.scirp.org

Cronbach, L. J. (1946). Response Sets and Test Validity. Educational and Psychological 
Measurement, 6, 475-494. https://journals.sagepub.com https://doi.org/10.1177/001316444600600405

Elnanga, A., \& Imran, A. (2013). The Effect of Training on Employee Performance. European Journal of Business and Management, 5, 137-148. https://www.scirp.org

Emerso, T. (2017). Inside the VA: How Workplace Training Evaluation Impacts Employee Performance. Doctor of Education, University of Missouri. https://irl.umsl.edu

Gagne, R. M., Briggs, L. J., \& Wager, W. W. (1997). Selecting and Using Media: Principles of Instructional Design. https://www.niu.edu

Githinji, A. (2014). Effect of Training on Employee Performance: A Case Study of United Nations Support Office for the African Union Mission in Somalia. United States International University. http://erepo.usiu.ac.ke

Goldstein, I. L., \& Ford, J. K. (2002). Training in Organizations Needs Assessment, Development, and Evaluation. International Journal of Education and Research, 6, 1-12. https://www.scirp.org

Hamid, A. M., Salleh, A., \& Ismail, J. (1987). Management Education in Malaysia. In J. H. Tan, \& P. S. You (Eds.), Developing Managers in Asia (108 p). Addison-Wesley. https://www.ijbm.org

Harrison, R. (2000). Employee Development. International Journal of Scientific and Research Publications, 6, 266-270. https://amazon.com

Hartoyo, R., \& Efendy, H. (2017). Development of Training Needs Analysis in Organization. Journal of Management Research, 9, 140-160. https://www.econbiz.de

Humphrey, A., Chege, K., \& Douglas, M. (2013). Effect of Training Dimensions on Employee's Work Performance: A Case of Mumias Sugar Company in Kakamega County. International Journal of Business and Management Invention, 2, 138-149. https://www.ijbmi.org

Huselid, M. A. (1995). The Impact of Human Resource Management Practices on Turnover, Productivity and Corporate Financial Performance. Academy of the Management Journal, 38, 635-672. https://www.researchgate.net https://doi.org/10.5465/256741

Huyen, N. (2014). How Training Influences Employee Performance. Master of Business Administration, Vietnam National University. https://documents.pub

McCourt, W., \& Eldridge, D. (2003). Global Human Resources Management: Managing People in Developing and Transitional Countries (p. 382).

https://www.researchgate.net

Megan, M. (2017, August). What You Need to Know about Training Contents. https://www.td.org

Mohammed, O. (2018). The Evaluation of Training and Development of Employees: The Case of a National Oil and Gas Industry. Thesis for the Degree of Doctor of Philosophy, Brunel University. https://www.researchgate.net

Mutisya, L., Tho, A., \& Mutegi, D. (2017). Effect of Training Needs Assessment on Organizational Performance in the Counties in Kenya: A Case Study of City Country of Nairobi. International Journal of Current Aspects in Human Resource Management, 1, 44-59. https://www.ijcab.org

Nassazi, A. (2013). Effects of Training on Employee Performance: Evidence from Uganda Finland. Vaasan Ammattikorkeakoulu University of Applied Sciences, Business Economics and Tourism. https://www.researchgate.net

Olaniyan, D., \& Ojo, R. (2008). Staff Training and Development: A Vital Tool for Orga- 
nisational Effectiveness. European Journal of Scientific Research, 24, 326-331.

https://www.semanticscholar.org

Pfeffer, J. (1994). Competitive Advantage through People. Management Review, 36, 9-28. https://www.scirp.org https://doi.org/10.2307/41165742

Roberts, T. G. (2006). A Philosophical Examination of Experiential Learning Theory for Agricultural Educators. Journal of Agricultural Education, 47, 17-29.

https://www.researchgate.net https://doi.org/10.5032/jae.2006.01017

Sultana, A., Irum, S., Ahmed, K., \& Mehmood, N. (2012). Impact of Training on Employee Performance: A Study of Telecommunication Sector in Pakistan. Interdisciplinary Journal of Contemporary Research in Business, 6, 646-661.

https://www.semanticscholar.org

Swart, J., Mann, C., Brown, S., \& Price, A. (2005). Human Resource Development: Strategy and Tactics. Journal of Business and Management Sciences, 4, 32-39. https://www.reseachgate.net

Tahir, N. (2014). The Impact of Training and Development on Employees Performance and Productivity: A Case Study of United Bank Limited Peshawar City, KPK, Pakistan. International Journal of Academic Research in Business and Social Sciences, 4, 86-98. https://www.researchgate.net https://doi.org/10.6007/IJARBSS/v4-i4/756

Torrinton, P., Hall, K., Taylor, L., \& Atkinson, R. (2005). Human Resource Management. Prentice Hall. http://www.ilt.edu.vn

Wagonhurst, C. (2002). Developing Effective Training Programs. Journal of Research Administration, 5-10. https://www.researchgate.net

Wanigasingha, S. S., Madhawa, D., Premashantha, J., Fernando, Mullekanda, K., \& Atapattu, A. (2018). Impact of Employees Training on Their Work Performance with Reference to ABC Pvt. Hospital in Sri Lanka. Journal of Business and Management, 40-47. https://researchgate.net

Wexley, N., \& Latham, G. (2002). Developing and Training Human Resources in Organization (3rd ed., pp. 138-147). Prentice Hall. https://books.google.com

Wright, P., \& Geroy, G. (2001). Changing the Mindset: The Training Myth and the Need for Word-Class Performance. International Journal of Human Resource Management, 5, 38-42. https://www.ingentaconnect.com 